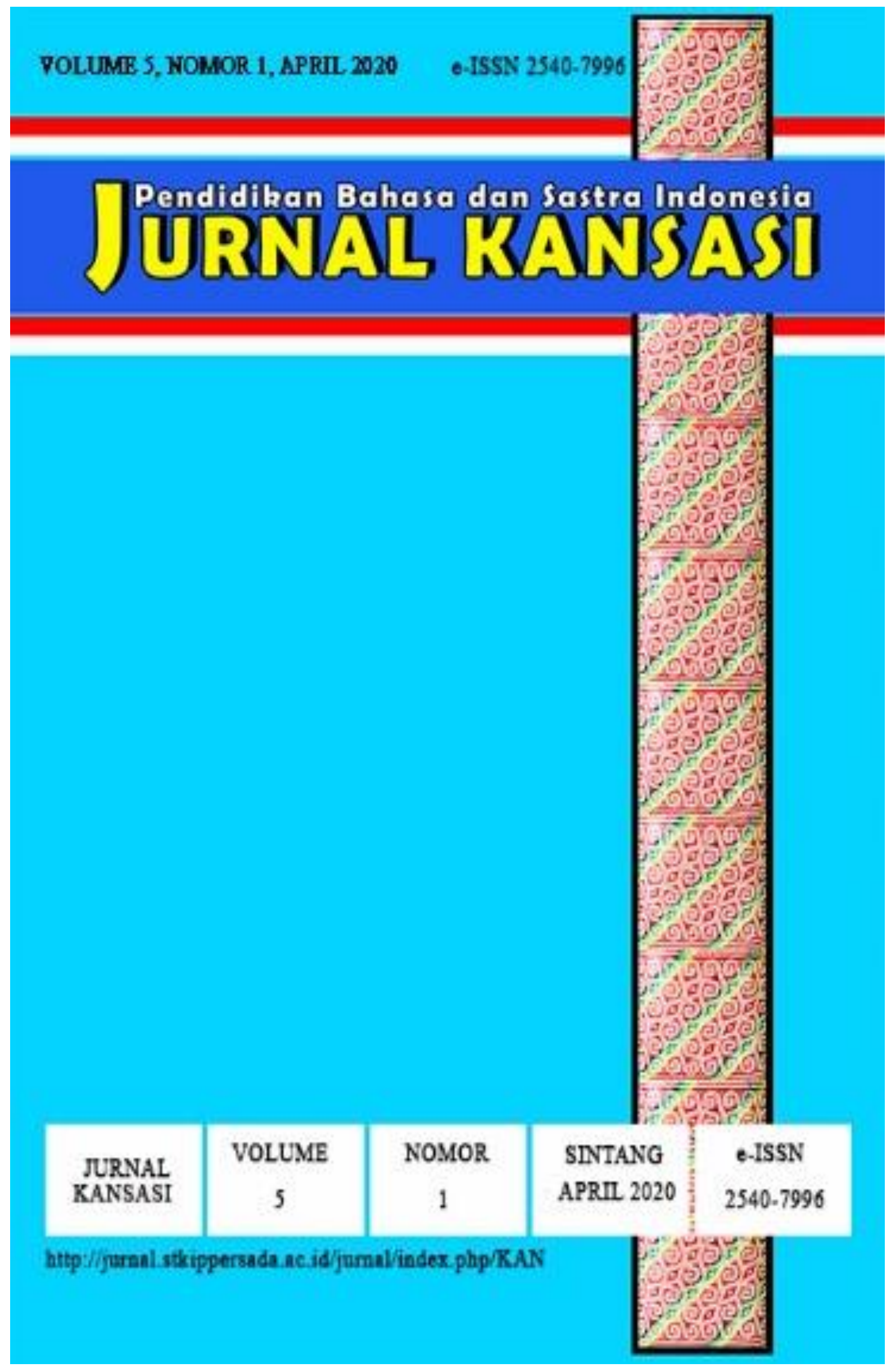




\section{JURNAL KANSASI \\ Volume 5, Nomor 1, April 2020}

Jurnal online pendidikan bahasa dan sastra Indonesia terbit dua kali setahun yaitu pada bulan April dan Oktober. Berisi tulisan yang diangkat dari hasil telaah dan penelitian di bidang pendidikan, bahasa, dan sastra Indonesia.

\section{Editor In Chief}

Debora Korining Tyas

\section{Deputy Chief Editor}

Sri Astuti

\section{Editor}

Tedi Suryadi

Ursula Dwi Oktaviani

Yudita Susanti

Muhammad Thamimi

Muchammad Djarot

\section{Reviewer}

Yusuf Olang

Herpanus

Bani Sudardi

Yoseph Yapi Taum

Agus Wartiningsih

\section{Administratative Staffs \\ Valentinus Ola Beding \\ Evi Fitrianingrum}

Alamat Redkasi: Program Studi Pendidikan Bahasa dan Sastra Indonesia STKIP Persada Khatulistiwa Sintang, Jl. Pertamina Sengkuang, Kotak Pos 126, Hp/WA. 082150544710.

Website e-journal KANSASI: http://jurnal.stkippersada.ac.id/jurnal/index.php/KAN

Jurnal ilmiah online KASASI diterbitkan oleh Program Studi Pendidikan Bahasa dan Sastra Indonesia STKIP Persada Khatulistiwa Sintang. Terbit sejak April 2016.

Penyunting menerima tulisan ilmiah yang belum pernah diterbitkan dimedia lain, baik cetak maupun elektronik. Naskah diketik untuk ukuran HVS A4 dengan spasi satu koma lima, maksimal 20 halaman. Tulisan yang masuk direview dan selanjutnya untuk diterbitkan. 


\section{JURNAL KANSASI \\ Volume 5, Nomor 1, April 2020}

\section{DAFTAR ISI}

Halaman

Hubungan Kemandirian Belajar Terhadap Hasil Belajar Siswa pada Mata Pelajaran Bahasa Indonesia Kelas VIII $1-8$

SMP N 02 Tempunak

\section{Herpanus, Evi Fitria Ningrum, Ahensius Bantut}

STKIP Persada Khatulistiwa Sintang

Analisis Kesulitan Membaca Permulaan pada Sub Tema Tugasku

Sebagai Umat Beragama pada Siswa Kelas II SD Negeri 06

Setapang Laut Ketungau Hilir

Ursula Dwi Oktaviani, Gabriel Serani, Etikustini

STKIP Persada Khatulistiwa Sintang

Analisis Struktural Kumpulan Cerita Rakyat

Dayak Jangkang Tanjung

Valentinus Ola Beding, Tedi Suaryadi, Frideta Heni

STKIP Persada Khatulistiwa Sintang

Peningkatan Keterampilan Menulis Karangan Deskripsi

Menggunakan Media Miniatur (Maket)

Debora Korining Tyas, Sudarto, Ahmad Ridho Inoviar

STKIP Persada Khatulistiwa Sintang

Hubungan Kebiasaan Menulis dengan Kemampuan Menulis Cerpen pada Siswa Kelas XI Sekolah Menengah Atas

Nusantara Indah Sintang

Yusuf Olang, Evi Fitrianingrum, Markulanus Alex

$55-63$

STKIP Persada Khatulistiwa Sintang

Peningkatan Hasil Belajar Siswa Menggunakan

Metode Talking Stick pada Pembelajaran Tematik

Tedi Suryadi, Meranti Sintauli Tampubolon

$64-70$

STKIP Persada Khatulistiwa Sintang

Peningkatan Penguasaan Kosakata Bahasa Indonesia

Menggunakan Media Gambar pada Siswa Kelas 1

Sekolah Dasar Negeri 43 Tapang Aceh Tahun Ajaran 2019/2020

$71-80$

Gabriel Serani, Ilinawati, Lidia Heni

STKIP Persada Khatulistiwa Sintang 
Hubungan Hasil Belajar Siswa Dengan Kemampuan

Menerapkan Nilai-Nilai Pancasila

Agnesia Hartini, Lukas Robinson

$81-91$

STKIP Persada Khatulistiwa Sintang

Proses Dan Makna Simbol Ritual Munjong Dayak Tobag

Yudita Susanti, Yusuf Olang, Marselina Risca

$92-98$

STKIP Persada Khatulistiwa Sintang

Penerapan Pendekatan Eksploratory Discovery untuk Meningkatkan

Motivasi dan Hasil Belajar Kognitif

Sirilus Sirhi, Hendrikus Julung, Valentina Suci Susanti

$99-112$

STKIP Persada Khatulistiwa Sintang

Analisis Makna Bahasa Promosi Katalog Oriflame

Edisi Bulan Januari-Maret Tahun 2019

$113-126$

Ursula Dwi Oktaviani, Debora Korining Tyas, Ira Winarti

STKIP Persada Khatulistiwa Sintang

Peran Guru Pkn dalam Membina Civic Skill Siswa

Sekolah Menengah Pertama Negeri 7

Agnesia Hartini, Simon Petrus

$127-137$

STKIP Persada Khatulistiwa Sintang 
Vol. 5, No. 1, April 2020

e-ISSN: 2540-7996

http://jurnal.stkippersada.ac.id/jurnal/index.php/KAN/index

\title{
HUBUNGAN KEBIASAAN MENULIS DENGAN KEMAMPUAN MENULIS CERPEN PADA SISWA KELAS XI SEKOLAH MENENGAH ATAS NUSANTARA INDAH SINTANG
}

\author{
Yusuf Olang', Evi Fitrianingrum², Markulanus Alex ${ }^{3}$ \\ ${ }^{1}$ STKIP Persada Khatulistiwa, ${ }^{2}$ STKIP Persada Khatulistiwa, \\ ${ }^{3}$ STKIP Persada Khatulistiwa, \\ e-mail:, Yusufolang@gmail.com ${ }^{1}$, fitrianingrumEvi250@gmail.com², \\ alexmarkulanus@gmail.com ${ }^{3}$
}

Diajukan, 6 Februari 2020, Diterima, 4 Maret 2020, Dterbitkan, 1 April 2020

\begin{abstract}
ABSTRAK
Masalah dalam penelitian ini yaitu bagaimanakah Hubungan Kebiasaan Menulis dengan Kemampuan Menulis Cerpen Pada Siswa Kelas XI Sekolah Menengah Atas Nusantara Indah Sintang Tahun Pelajaran 2018/2019?. Metode yang digunakan dalam penelitian ini adalah metode kuantitatif dan bentuk penelitiannya studi korelasi. Populasi dalam penelitian ini adalah siswa kelas XI sekolah menengah atas nusantara indah sintang tahun pelajaran tahun 2018/2019, dengan sampel keseluruhan siswa kelas XI IPS III yang berjumlah 32 orang. Teknik dan alat pengumpulan data yang digunakan adalah teknik komunikasi tidak langsung dengan alat ukur berupa lembar angket dan teknik dokumentasi dengan alat pengumpulan data berupa dokumentasi. Berdasarkan hasil analisis data penelitian, maka dapat disimpulkan bahwa: 1) kebiasaan menulis termasuk dalam kategori tinggi terbukti 32 siswa yang dijadikan sampel dalam penelitian ini memperoleh skor rata-rata 79,47 dengan skor tertinggi 100 dan terendah 50. 2) kemampuan menulis cerpen siswa termasuk dalam kategori cukup, ini terlihat dari 32 siswa memperoleh nilai rata-rata 47,46 dengan nilai tertinggi 75 dan nilai terendah 32 . 3) Hubungan Kebiasaan Menulis dengan Kemampuan Menilis Cerpen Pada Siswa Kelas XI Sekolah Menengah Atas Nusantara Indah Sintang termasuk dalam kategori kuat yaitu sebesar 0,625. Dari hasil penelitian, tingkat korelasi kedua variabel dalam penelitian ini dapat terjawab bahwa terdapat hubungan yang positif antara Kebiasaan Menulis dengan Kemampuan Menulis Cerpen Pada Siswa Kelas XI Sekolah Menengah Atas Nusantara Indah Sintang Tahun Pelajaran 2018/2019.
\end{abstract}

Kata kunci: Kebiasaan Menulis, Kemampuan Menulis Cerpen 
Vol. 5, No. 1, April 2020

e-ISSN: 2540-7996

http://jurnal.stkippersada.ac.id/jurnal/index.php/KAN/index

\begin{abstract}
The problem in this research is how is the correlation between Writing Habits and Short Story Writing Ability of students in class XI students of SMA Nusantara Indah Sintang in the Academic Year 2018/2019. The method used in this study is quantitative method in the form of correlation study. The population in this study were 32 stduents of class XI IPS III of SMA Nusantara Indah Sintang in the Academic Year 2018/2019. Tehniques and tools of data collection are indirect comunication tehnique with the measurement tools in the forms of questionnaire and documentation, the tool of data collection is document. Based on the results, it can be concluded that: 1) writing habits is was categorized as in high category, that was proven by 32 students who were sampled in this research obtained an average score of 79.47 with the highest score of 100 and the lowest 50.2) the ability to write short stories of students included in the sufficient category, it can be seen from 32 students obtained an average score of 47.46 with the highest score of 75 and the lowest score of 32.3) Correlation between Writing Habits and Short Story Writing Ability of Students in Class XI Students of SMA Nusantara Indah Sintang is categorized in the strong category that is 0.625 . From the results of the research, the level of correlation between the two variables in this study can be answered that there is a positive correlation between writing habit and short story writing ability students in class XI of Nusantara Indah Sintang in the Academic Year 2018/2019
\end{abstract}

Keyword: Writing Habit, Short Story Writing Ability 
Vol. 5, No. 1, April 2020

e-ISSN: 2540-7996

http://jurnal.stkippersada.ac.id/jurnal/index.php/KAN/index

PENDAHULUAN

Proses belajar merupakan aktivitas yang sangat penting, karena melalui proses belajar tujuan pendidikan akan dapat tercapai dalam bentuk perubahan tingkah laku siswa. Hal ini senada dengan bunyi Undang-undang Sistem Pendidikan Nasional No. 20 Pasal 3 Tahun 2003, yaitu :"Pendidikan nasional bertujuan untuk berkembangnya potensi peserta didik agar menjadi manusia yang beriman, bertaqwa kepada Tuhan Yang Maha Esa, berakhlak mulia, sehat, berilmu, cakap, kreatif, mandiri, dan menjadi warga negara yang demokratis serta bertanggung jawab".

Hal yang dapat dilakukan untuk mencapai tujuan pendidikan tersebut dalam pelajaran Bahasa Indonesia yaitu guru dapat mengembangkan empat keterampilan berbahasa, seperti keterampilan menyimak, keterampilan berbicara, keterampilan membaca dan keterampilan menulis. Salah satu komponen keterampilan bahasa yang harus dimiliki siswa adalah keterampilan menulis. Menulis merupakan salah satu keterampilan berbahasa yang sangat penting dalam kehidupan manusia. Dalman (2015 : 1) menyatakan menulis berarti menurunkan atau melukiskan lambang-lambang grafis yang menggambarkan suatu Bahasa yang dialami oleh seseorang. Dalam kegiatan menulis ini, penulis haruslah terampil memanfaatkan grafologi, struktur bahasa, dan kata. Keterampilan menulis ini tidak akan datang secara otonomi, tetapi harus melalui latihan dan praktik yang banyak serta teratur.

Kebiasaan menulis menjadi hal yang sangat penting, karena dengan demikian maka akan tertanam semangat untuk terus belajar dan menganggap bahwa menulis merupakan suatu kewajiban yang harus dilaksanakan sesuai dengan waktu yang sudah ditetapkan. Kebiasaan merupakan suatu tindakan atau perbuatan yang dilakukan secara berulang-ulang sehingga menjadi kebiasaan untuk melakukannya. Demikian pula halnya dengan kebiasaan dalam menulis, dimana seseorang akan diawali oleh sikap atau tindakan untuk memulai menulis dengan melakukannya berulang kali sehingga menjadi terbiasa bahkan berubah menjadi suatu kebiasaan.Kebiasaan menulis dapat dilatih dengan cara mengekspresikan diri dari sesuatu yang telah dipikirkan dan dirasakan mengenai diri sendiri maupun orang lain kemudian dituangkan dalam tulisan.Seseorang yang memiliki kebiasaan menulis akan berdampak dan terlihat pada kemampuannya, yaitu menjadilebih mahir dan baik dalam kegiatan menulis. Dengan memiliki kebiasaan menulis maka seseorang juga akan memiliki kemampuan menulis yang sangat baik.

Kemampuan menulis ini membuat orang perlu menguasai keterampilan-keterampilan menulis. Maksud dan tujuan menulis hanya dapat dicapai dengan baik oleh orang-orang yang dapat menyusun sebuah pemikiran dan menyatakannya dengan jelas. Kejelasan ini bergantung pada pikiran, pemakaian kata-kata, dan struktur kalimat. Hal tersebutlah yang mengimplikasikan menulis membutuhkan pemikiran yang cukup luas pula sehingga menulis pun memiliki persyaratan. Menulis bukan hanya sekedar menuliskan apa yang diucapkan (membahasatuliskan bahasa lisan), melainkan suatu kegiatan yang terorganisir sedemikian rupa sehingga terjadi suatu tindak komunikasi. Bila apa yang 
Vol. 5, No. 1, April 2020

e-ISSN: 2540-7996

http://jurnal.stkippersada.ac.id/jurnal/index.php/KAN/index

dimaksudkan oleh penulis sama dengan apa yang dimaksudkan oleh pembaca, seseorang dapat dikatakan terampil menulis, begitu pula dengan menulis karya sastra.

Sastra sebagai hasil pekerjaan seni kreasi manusia tidak akan pernah lepas dari bahasa yang merupakan media utama dalam karya sastra. Sastra dan manusia erat hubungannya karena pada dasarnya keberadaan sastra sering bermula dari persoalan-persoalan dan permasalahan yang ada pada manusia serta lingkungannya. Kemudian dengan adanya imajinasi yang tinggi, seorang pengarang tinggal menuangkan masalah-masalah yang ada di sekitarnya menjadi sebuah karya sastra. Sebagai sebuah karya imajiner, karya sastra menawarkan berbagai permasalahan manusia dan kemanusiaan, hidup dan kehidupan. Pengarang menghayati berbagai permasalahan tersebut dengan penuh kesungguhan yang kemudian diungkapkan kembali melalui sarana fiksi sesuai dengan pandangannya.

Menulis cerpen merupakan aktivitas yang dilakukan seseorang untuk menceritakan sesuatu melalui tulisan, agar pembaca tahu tentang apa yang dialami, diimpikan, dikhayalkan maupun yang dipikirkan penulis. Menurut Kurniawan (Susiana, 2014: 112) menyatakan bahwa cerpen (cerita pendek sebagai genre fiksi) adalah rangkaian peristiwa yang terjalin menjadi satu yang di dalamnya terjadi konflik antar tokoh atau dalam diri tokoh itu sendiri dalam latar dan alur. Peristiwa dalam cerita pendek berwujud hubungan antar tokoh, tempat dan waktu yang membentuk kesatuan. Cerpen merupakan genre fiksi yang rangkaian peristiwanya pendek dan menghadirkan satu konflik dalam satu persoalan. Jadi, dapat disimpulkan bahwa menulis cerpen merupakan kegiatan menuangkan pikiran ke dalam bahasa tulis melalui kalimat-kalimat berupa rangkaian peristiwa yang terjalin menjadi satu yang di dalamnya terjadi konflik antartokoh atau dalam diri tokoh itu sendiri dalam latar dan alur yang membentuk kesatuan.

Berdasarkan hasil praobservasi yang penulis lakukan di Sekolah Menengah Atas Nusantara Indah Sintang tahun pelajaran 2018/2019, diketahui bahwa pembelajaran di Sekolah Menengah Atas Nusantara Indah Sintang dalam pembelajaran Bahasa Indonesia khususnya kemampuan menulis cerpen tergolong kurang. Dari hasil wawancara yangdilakukan peneliti dengan guru Bahasa Indonesia yang mengajar di Sekolah Menengah Atas Nusantara Indah Sintang, menyatakan bahwa pembelajaran Bahasa Indonesia dalam menulis cerpen tergolong kurang.Hal tersebut diakibatkan kurangnya minat dankebiasaan menulis pada siswa, khususnya dalam menulis cerpen sertakurangnya kesadaran yang dimiliki siswa untuk mengetahui pelajaran yang berhubungan dengan menulis pada pelajaran Bahasa Indonesia. Melihat gejala dan data inilah yang membuat peneliti tertarik untuk mengadakan penelitian guna untuk mengetahui bagaimanakah hubungan kebiasaan menulis dengan kemampuan menulis cerpen pada siswa kelas XI Sekolah Menengah AtasNusantara Indah Sintang tahun pelajaran 2018/2019.Penelitian ini dilakukan untuk mengetahui adakah hubungan kebiasaan menulis dengan kemampuan menulis cerpen pada siswa kelas XI Sekolah Menengah Atas Nusantara Indah Sintang tahun pelajaran 2018/2019. 
Vol. 5, No. 1, April 2020

e-ISSN: 2540-7996

http://jurnal.stkippersada.ac.id/jurnal/index.php/KAN/index

METODE PENELITIAN

Penelitian ini mengunakan suatu pendekatan yang disebut dengan pendekatan kuantitatif. hal ini sesuai dengan pendapat (Sugiyono 2014: 8) yaitu metode penelitian kuantitatif dapat diartikan sebagai metode penelitian yang berlandaskan pada filsafat positivisme, digunakan untuk meneliti pada populasi dan sampel tertentu, pengumpulan data menggunakan instrumen penelitian, analisis data bersifat kuantitatif/statistik, dengan tujuan untuk menguji hipotesis yang telah ditetapkan.

Kegiatan penelitian memerlukan suatu metode, yaitu metode penelitian yang merupakan cara yang digunakan seorang peneliti untuk melaksanakan penelitian atau dalam mengumpulkan data penelitiannya. Sugiyono (2012: 2) menyatakan bahwa metode penelitian pada dasarnya merupakan cara ilmiah untuk mendapatkan data dengan tujuan dan kegunaan tertentu atau merupakan cara ilmiah untuk mengumpulkan data dengan tujuan dan kegunaan tertentu dari suatu penelitian. Emzir (2008: 27) menyatakan bahwa pemilihan metode oleh seorang peneliti tergantung pada tujuannya, apakah untuk lebih mengkhususkan jenis informasi yang akan dikumpulkan dalam melanjutkan studi.

Metode penelitian yang digunakan dalam penelitian ini yaitu metode penelitiankuantitatif.Sugiyono (2012: 8) menyatakan bahwa metode penelitian kuantitatif dapat diartikan sebagai metode penelitian yang berlandaskan pada filsafat positivisme, digunakan untuk meneliti pada populasi atau sampel tertentu, pengumpulan data menggunakan instrumen penelitian, analisis data bersifat kuantitatif/statistik, dengan tujuan untuk menguji hipotesis yang telah ditetapkan.

Bentuk penelitian yang digunakan dalam penelitian ini adalah studi korelasi, yaitu melihat hubungan kebiasaan menulis dengan kemampuan menulis cerpen pada siswa kelas XI Sekolah Menengah Atas Nusantara Indah Sintang Tahun Pelajaran 2018/2019, yang dimaksudkan untuk menentukan tingkat hubungan variabel-variabel yang berbeda dalam suatu populasi. Menurut Sukardi (2003: 166)penelitian korelasi adalah suatu penelitian yang melibatkan tindakan pengumpulan data guna menentukan, apakah ada hubungan dan tingkat hubungan antara dua variabel atau lebih. Penelitian ini juga disebut sebagai penelitian ex post facto. Menurut Kerlinger (Emzir 2008: 119) penelitian kausal komparatif (causal comparative reseach) yang disebut juga sebagai penelitian ex post facto adalah penyelidikan empiris yang sistematis di mana ilmuan tidak mengendalikan variabel bebas secara langsung karena eksistensi dari variabel tersebut telah terjadi, atau karena variabel tersebut pada dasarnya tidak dapat dimanipulasi.

Menurut Muhidin (2011: 105) tujuan dilakukan analisis korelasi antara lain: (1) untuk mencari bukti terdapat tidaknya hubungan (korelasi) antarvariabel, (2) bila sudah ada hubungan, untuk melihat tingkat keeratan hubungan antarvariabel, dan (3) untuk memperoleh kejelasan dan kepastian apakah hubungan tersebut berarti (meyakinkan/signifikan) atau tidak berarti (tidak meyakinkan).

Penelitian ini diperlukan teknik dan alat pengumpul data yang tepat agar, pemecahan masalah dapat tercapai tingkat validitas yang mungkin diperoleh hasil yang objektif.Muhidin (2011: 19) menyatakan bahwa teknik pengumpulan data adalah cara yang dapat digunakan peneliti untuk mengumpulkan 
Vol. 5, No. 1, April 2020

e-ISSN: 2540-7996

http://jurnal.stkippersada.ac.id/jurnal/index.php/KAN/index

data.Teknik pengumpulan data penelitian ini adalah: (1) Teknik Komunikasi Tidak Langsung (2)

Teknik Studi Dokumentasi (3). Alat Yang Digunakan Dalam Pengumpulan Data Dari Penelitian Ini Yaitu: (1) Lembar Angket (Kuesioner) (2) Dokumentasi.Analisis data yang digunakan pada penelitian ini sebagai berikut: (1) Pengujian Validitas Isntrumen (2) Pengujian Reabilitas Instrumen.

\section{PEMBAHASAN}

Berdasarkan hasil temuan di lapangan, maka hasil penelitian dan pembahasan mengenai Hubungan Kebiasaan Menulis dengan Kemampuan Menulis Cerpen pada Siswa Kelas XI Sekolah Menengah Atas Nusantara Indah Sintang Tahun Pelajaran 2018/2019, adalah sebagai berikut :

1. Kebiasan Menulis

Dari hasil Penyebaran angket variabel kebiasaan menulis (X) dilakukan pada tanggal 10Desember 2018 yang bertujuanuntuk mengetahui kebiasaan menulis pada siswa kelas XI Sekolah Menengah Atas Nusantara Indah Sintang Tahun Pelajaran 2018/2019. Hasil angket variabel kebiasaan menulis (X)ini menggunakan skala likert dengan jumlah instrumen sebanyak 20 item pernyataan dan jumlah sampel sebanyak 32 siswa. Hasil penelitian menunjukkan bahwaKebiasaan Menulis Pada Siswa Kelas XI Sekolah Menengah Atas Nusantara Indah Sintang Tahun Pelajaran 2018/2019 tergolong tinggi, hal ini dibuktikan dari 32 siswa yang dijadikan sampel dalam penelitian ini memperoleh skor rata-rata sebesar 79,47 dengan skor tertinggi sebesar100 dan skor terendah sebesar50 Berdasarkan hasil angket tersebut, dapat disimpulkan bahwa Kebiasaan Menulis Pada Siswa Kelas XI Sekolah Menengah Atas Nusantara Indah Sintang Tahun Pelajaran 2018/2019 masuk dalam kategori tinggi (dikonsultasikan dengan kriteria penilaian hasil angket).

\section{Tabel 1}

Kriteria Penilaian Hasil Angket

\begin{tabular}{|c|c|c|}
\hline $\begin{array}{c}\text { Interval } \\
\text { Tingkat } \\
\text { Penguasaan }\end{array}$ & $\begin{array}{c}\text { Kategori } \\
\text { Nilai }\end{array}$ & Keterangan \\
\hline $85-100$ & $\mathrm{~A}$ & Sangat Tinggi \\
\hline $75-84$ & $\mathrm{~B}$ & Tinggi \\
\hline $45-74$ & $\mathrm{C}$ & Sedang \\
\hline $25-44$ & $\mathrm{D}$ & Rendah \\
\hline $0-24$ & E & $\begin{array}{c}\text { Sangat } \\
\text { Rendah }\end{array}$ \\
\hline
\end{tabular}

Sumber:Muhidin( Markus 2017:63)

2. Kemanpuan Menulis Cerpen (Y) 
Vol. 5, No. 1, April 2020

e-ISSN: 2540-7996

http://jurnal.stkippersada.ac.id/jurnal/index.php/KAN/index

Hasil penelitian tentang kemampuan menulis cerpen pada siswa di kelas XI Sekolah Menengah

Atas Nusantara Indah Sintang Tahun Pelajaran 2018/2019 diambil dari hasil nilai ulangan siswa. Tampak dari 32 siswa yang dijadikan sebagai sampel dalam penelitian ini memperoleh Nilai rata-rata 47,46, dengan nilai tertinggi 75 dan nilai terendah 32. Berdasarkan hasil nilai ulangan siswa tersebut, dapat disimpulkan bahwa kemampuan Menulis Cerpen Pada SiswaKelas XI Sekolah Menengah Atas Nusantara Indah Sintang Tahun Pelajaran 2018/2019 masuk dalam kategori cukup (dikonsultasikan dengan kriteria penilaian taraf keberhasilan belajar siswa).

Tabel 2

Kriteria Penilaian Taraf Beberhasilan Belajar Siswa

\begin{tabular}{|c|c|c|}
\hline $\begin{array}{c}\text { Interval } \\
\text { Tingkat } \\
\text { Penguasaan }\end{array}$ & $\begin{array}{c}\text { Kategori } \\
\text { Nilai }\end{array}$ & Keterangan \\
\hline $85-100$ & A & Baik Sekali \\
\hline $75-84$ & B & Baik \\
\hline $45-74$ & C & Cukup \\
\hline $25-44$ & D & Kurang \\
\hline $0-24$ & E & Sangat Kurang \\
\hline
\end{tabular}

Sumber : RPP Kelas XI

3. Hubungan Kebiasaan Menulis dengan Kemampuan Menulis Cerpen

Menurut Zainurrahman (2013: 2) menyatakan bahwa khususnya menulis, latihan merupakan kunci yang paling utama demi mencapai kesuksesan untuk mencapai predikat baik dan benar Membiasakan diri menulis sangat penting karena akan memudahkan kita untuk berpikir. Menulis juga dapat menolong kita berpikir secara kritis, dapat memudahkan kita merasakan dan menikmati hubungan-hubungan, memperdalam daya tanggap atau persepsi kita, memecahkan masalah-masalah yang kita hadapi, menyusun urutan bagi pengalaman.

Dengan adanya minat dan motivasi seseorang dalam mengembangkan kemampuan idenya dalam Bahasa tulis, maka tidak heran ketika seseorang yang mempunyai keterampilan untuk menulis tidak mengalami kesulitan untuk menuangkan idenya. Demikian juga halnya dengan menulis cerpen, Banyak orang beranggapan bahwa menulis cerita pendek sangat sulit namun sebenarnya di sisi yang lain jika kita memiliki tekad (kemauan). kemampuan dalam menulis dan kaya ide, maka pekerjaan menulis cerpenmenjadi hal yang mudah. Menurut Wiyanto (Rachmawati, 2013: 5) menulis cerpen harus banyak berkhayal karena cerpen memang karya fiksi yang berbentuk prosa. Peristiwa yang terjadi dalam cerpen hanya direkayasa pengarangnya. Demikian pula para pelaku yang terlibat dalam peristiwa itu. Waktu, tempat, 
Vol. 5, No. 1, April 2020

e-ISSN: 2540-7996

http://jurnal.stkippersada.ac.id/jurnal/index.php/KAN/index

dan suasana terjadinya peristiwa pun hanya direka-reka oleh pengarangnya. Oleh karena itu, cerpen (dan semua cerita fiksi) disebut cerita rekaan.

Berdasarkan hasil pelitian dari data yang telah dikumpulkan, kemudian peneliti mengolah data mengunakan rumus korelasi Product Moment. Dari hasil penelitian statistik kebiasaan menulis dengan kemampuan menulis cerpen, diketahui rata-rata kebiasaan menulis (X) sebesar 79,47 sedangkan kemampuan menulis cerpen (Y) rata-rata 47,46. setelah dilakukan perhitungan menggunakan rumus korelasi Product moment,maka diperoleh $t_{\text {hitung }}$ sebesar 4,382 dan $t_{\text {tabel }}$ sebesar 2,042. Artinya bahwa hipotesis nol (Ho) dalam penelitian ini ternyata ditolak karena hasil perhitungan $t_{\text {hitung }}$ menunjukkan hasil positif yaitu 4,382 Sedangkan $t_{\text {tabel }} 2,042$ dengan taraf kepercayaan $5 \%$ atau $0,05 \mathrm{dk}(\mathrm{n}-2),(32-2)=30$.

Jadi thitung besar dari tabel $(4,382>02,042)$, dengan demikian hipotesis alaternatif (Ha) diterima dan mendapat hubungan yang signifikan antara kebiasaan menulis dengan kemampuan menulis cerpen pada siswa kelas XI Sekolah Menengah Atas Nusantara Indah Sintang Tahun Pelajaran 2018/2019.

\section{SIMPULAN}

Berdasarkan uraian hasil penelitian dan pembahasan diatas, maka dapat disimpilkan sebagai berikut:

1. Kebiasaan Menulis Pada Siswa Kelas XI Sekolah Menengah Atas Nusantara Indah Sintang termasuk kategori tinggi, tampak dari 32 siswa yang dijadikan sampel dalam penelitian ini memperoleh skor rata-rata 79,47 dengan skor tertinggi 100 dan terendah 50 menunjukkan bahwa kebiasaan menulis masuk dalam kategori tinggi.

2. Kemampuan Menulis Cerpen Pada Siswa Kelas XI Sekolah Menengah Atas Nusantara Indah Sintang termasuk kategori cukup, berdasarkan hasil nilai ulangan siswa tampak dari 32 siswa yang dijadikan sebagai sampel dalam penelitian ini memperoleh nilai rata-rata 47,46dengan nilai tertinggi 75 dan nilai terendah 32, Berdasarkan hasil nilai ulangan siswa tersebut, dapat disimpulkan bahwa Kemampuan Menulis Cerpen Pada SiswaKelas XI Sekolah Menengah Atas Nusantara Indah Sintang Tahun Pelajaran2018/2019 masuk dalam kategori cukup.

3. Terdapat atau adanya hubungan yang signifikan sedang Antara Kebiasaan Menulis Dengan Kemampuan Menulis Cerpen Pada Siswa Kelas XI Sekolah Menengah Atas Nusantara Indah Sintang Tahun Pelajaran 2018/2019 sebesar 0,625 (kategori kuat) dengan kofisien determinan (KP) sebesar $39,06 \%$. Sedangkan sisanya $60,94 \%$ ditentukan oleh faktor kebiasaan menulis lainnya seperti menulis puisi.

\section{DAFTAR PUSTAKA}

Dalman. 2015. Menulis Karya Ilmiah. Jakarta: Raja Grafindo Persada. 
Vol. 5, No. 1, April 2020

e-ISSN: 2540-7996

http://jurnal.stkippersada.ac.id/jurnal/index.php/KAN/index

Emzir. 2008. Metodologi Penelitian Pendidikan Kuantitaif \& Kualitatif. Jakarta: PT Rajagrafindo Persada.

Muhidin, Sambas Ali. 2011. Analisis Korelasi, Regresi, dan Jalur dalam Penelitian. Bandung: Pustaka Setia.

Rachmawati, Levita. 2013. Kemampuan Menulis Cerpen Siswa Kelas X 1 SMA PGRI 2 Kota Jambi Tahun Pelajaran 2013/2014. Artikel Ilmiah: Fakultas Keguruan dan Pendidikan Universitas Jambi.

Sugiyono. 2012. Metode Penelitian Kuantitatif, Kualitatif dan R\&D. Bandung: Alfabeta.

Sugiyono. 2014. Statistik untuk penelitian. Bandung: Alfabeta.

Sukardi. 2017. Metodologi Penelitian Pendidikan. Jakarta: Bumi Aksara.

Susiana. 2014. Peningkatan Kemampuan Menulis Cerpen dengan Media Videoklip pada Siswa Kelas XI F SMP Negeri 2 Kalitidu Bojonegoro. Jurnal Edu-Kata,Vol.1, No.2, Agustus 2014: 111-118.

Zainurrahman. 2013. Menulis Dari Teori Hingga Praktik. Bandung: Alfabeta. 


\section{Petunjuk Bagi (Calon) Penulis Jurnal KANSASI}

1. Artikel yang ditulis untuk Jurnal KANSASI adalah hasil telaah dan hasil penelitian dibidang pendidikan, bahasa, dan sastra Indonesia serta tidak pernah diterbitkan dimedia lain, baik cetak maupun elektronik.

2. Naskah diketik dengan huruf Times New Romans, ukuran 12, dengan spasi 1,5, menggunakan kertas A4, margin atas, kiri, kanan dan bawah $2.54 \mathrm{~cm}$, dengan maksimum 20 halaman, dan diserahkan secara online melalui laman (http://jurnal.stkippersada.ac.id/jurnal/index.php/KAN) pada bagian submission, dan terlebih dahulu penulis melakukan registrasi sebagai penulis (author). Pada saat diserahkan, file dalam format $p d f$.

3. Nama penulis artikel dicantumkan tanpa gelar akademik dan di tempatkan di bawah judul artikel. Nama penulis hendaknya dilengkapi dengan alamat lembaga tempat penelitian serta alamat korespondensi. Bila naskah ditulis oleh tim, maka penyunting hanya berhubungan dengan penulis utama.

4. Artikel ditulis dalam bahasa Indonesia dengan format esai, disertakan judul masingmasing bagian artikel. Judul artikel dicetak dengan huruf kapital dengan posisi tengah atas dengan ukuran huruf 14 serta ditebalkan.

5. Sistematika artikel hasil telaah adalah: judul, nama penulis (tanpa gelar), identitas lembaga, alamat e-mail, abstrak (maksimum 250 kata), kata kunci, pendahuluan; pembahasan, simpulan, dan daftar pustaka.

6. Sistematika artikel hasil penelitian adalah: judul, nama penulis (tanpa gelar), abstrak (maksimum 250 kata), pendahuluan, metode penelitian, pembahasan, simpulan, dan daftar pustaka.

7. Sumber rujukan minmal terbitan sepuluh tahun terkahir. Rujukan yang diutamakan adalah sumber-sumber primer berupa laporan penelitian, atau artikel penelitian terbitan jurnal ilmiah.

8. Perujukan, pengutipan, tabel, dan gambar menggunakan ketentuan yang ada pada template penulisan artikel ilmiah pada Jurnal KANSASI.

9. Naskah diketik sesuai dengan tata bahasa baku bahasa Indonesia.

10. Setiap naskah ditelaah oleh penyunting ahli (reviewer) yang ditunjuk oleh penyunting sesuai dengan bidang kepakaran. Penulis artikel diberi kesempatan untuk merivisi naskah berdasrkan rekomendasi dari penyunting. Pemuatan atau penolakan naskah akan diberitahukan secara online melalui e-mail.

11. Penyuntingan naskah pra-terbit dikerjakan oleh penyunting (editor). Naskah pra-terbit dapat batal diterbitkan apabila diketahui bermasalah.

12. Segala sesuatu yang menyangkut perizinan atau penggunaan software computer untuk pembuatan naskah atau hal lain yang terkait dengan pelanggaran hak cipta yang dilakukan oleh penulis, serta konsekuensi hukum yang mungkin timbul karenanya, sepenuhnya menjadi tanggungjawab penulis. 